\title{
Analisis Kuantitatif Minyak Atsiri Dari Serai (Cymbopogon sp) Sebagai Aromaterapi
}

\section{Quantitative Analysis Of Essential Oil From Lemongrass (Cymbopogon sp) As Aromaterapy}

\author{
Udrika Lailatul Qodri \\ Program Studi Farmasi, Fakultas Ilmu Kesehatan, Universitas Ibrahimy \\ Email: udrika_lq@ibrahimy.ac.id
}

\begin{abstract}
ABSTRAK
Peningkatan kebutuhan terhadap minyak atsiri berbanding lurus dengan perkembangan industry modern dibidang industry parfum, makanan, kosmetik, obat-obatan dan aroma terapi. Tanaman serai memiliki potensi sebagai penghasil minyak atsiri dan bisa dimanfaatkan sebagai aromaterapi. Tujuan dari penelitian ini untuk menganalisa secara kuanitatif minyak atsiri dari tanaman serai (Cymbopogon sp.) sebagai aromaterapi. Penelitian ini termasuk penelitian deskriptif kuantitatif yaitu ekstraksi tanaman serai yaitu bagian batang, bahan yang digunakan adalah simplisia dan tahapan selanjutnya menganalisa mutu simplisia (kadar air) dan identifikasi minyak atsiri (rendemen, ujiorganoleptik dan bobot jenis). Hasil penelitian menunjukkan kadar air simplisia serai sebesar 6\%, Presentase rendemen yang paling tinggi pada sampel kering yaitu $0.72 \%$. Hasil organoleptik menunjukkan minyak atsiri dari simplisia serai berwarna kuning muda, berbau khas aromatic, rasa pahit dan bobot jenis $0.878 \mathrm{gr} / \mathrm{ml}$.
\end{abstract}

Kata Kunci: Tanaman Serai, Minyak Atsiri, Aromaterapi

\section{ABSTRACT}

The increasing need for essential oils is directly proportional to the development of modern industries in the fields of perfume, food, cosmetics, medicine and aroma therapy industries. Lemongrass plant has the potential to produce essential oils and can be used as aromatherapy. The purpose of this study was to quantitatively analyze the essential oil of lemongrass (Cymbopogon sp.) As aromatherapy. This research is a quantitative descriptive study, namely the extraction of lemongrass, namely the part of the stem, the material used is simplicia and the next stage is to analyze the quality of simplicia (moisture content) and the identification of essential oils (yield, organoleptic testing and specific gravity). The results showed that the water content of lemongrass simplicia was $6 \%$, the highest yield percentage in dry samples was $0.72 \%$. The organoleptic results showed that the essential oil of lemongrass simplicia was light yellow, had a distinctive aromatic smell, had a bitter taste and a specific gravity of $0.878 \mathrm{gr} / \mathrm{ml}$.

Keywords: Lemongrass Plant, Essential Oil, Aromatherapy

\section{PENDAHULUAN}

$$
\text { Tingkat keanekaragaman }
$$

tanaman di Indonesia dalam

menghasilkan minyak atsiri termasuk

yang sangat tinggi. Meningkatnya

pemanfaatan tumbuhan yang berpotensi

mengahasilkan minyak atsiri berbanding lurus terhadap kebutuhan minyak atsiri dunia, hal ini juga berdampak pada perkembangan industri modern yang bergerak dibidang kesehatan, pangan, kosmetik dan industri (Feriyanto, 2013). Pemanfaatan minyak atsiri dibidang kesehatan yaitu 
sebagai antiseptik, antiinflamasi, analgesik dan sedatif. Di Indonesia saat ini juga memanfaatkan minyak atsiri sebagai komoditas ekspor yang berasal dari tanaman nilam, pala, akar wangi, lada, kenanga, cendana, cengkeh, kayu manis dan serai. Minyak atsiri memiliki sifat mudah menguap dan biasanya berwujud cair dan dapat diisolasi dari bagian tanaman seperti akar, batang, daun, bunga, buah dan biji. Proses ekstraksi minyak atsiri biasanya menggunakan pelarut organik maupun dengan cara di pres/kempa dan bisa dilakukan secara enzimatik. Pemanfaatan lainnya yaitu sebagai bahan dasar pembuatan sabun dan aroma terapi (Yuliani dan Satuhu, 2012).

Berdasarkan komponen atau penyusun minyak atsiri dapat dibagi menjadi dua yaitu minyak atsiri yang mudah dan sulit dipisahkan dengan penyusun murninya. Minyak atsiri yang mudah dipisahkan misalnya minyak serai, minyak daun cengkeh. Sedangkan minyak yang sulit dipisahkan dengan penyusun murninya yaitu minyak nilam dan minyak kenanga (Sastrohamidjojo, 2004). Faktor yang mempengaruhi hasil minyak atsiri adalah umur tanaman dan curah hujan (Guenther, 1990).
Tanaman serai (Cymbopogon sp.) memiliki akar serabut dan habitus herba (golongan rumput). Batang tingginya antara 50-100 cm, bulat pipih, warna putih-coklat. Daunnya lanset, tulang daun sejajar, berwarna hijau dan permukaan daun kasar. Kandungan yang utama dalam tanaman serai secara umum mengandung flavonoid, saponin, polifenol dan minyak atsiri (Depkes RI, 2001). Proses ekstraksi minyak atsiri pada setiap bagian tanaman berbedabeda misalnya pada bunga dilakukan dengan cara penyulingan dan herba dilakukan dengan cara destilasi. Prinsipnya proses destilasi bertujuan untuk mengisolasi atau memisahkan dua atau lebih komponen zat cair berdasarkan titik didihnya. Pada proses destilasi ada yang menggunakan air dan akan berkontak langsung dengan bahan sehingga dikenal dengan hidrodestilasi. Hasil dari proses destilasi biasanya masih berupa minyak atsiri kasar yaitu mengandung air atau pelarut lainnya, sehingga harus dilakukan proses lanjutan dengan cara menarik air dalam minyak atsiri dengan kualitas bagus dan biasanya jernih (Sastrohamidjojo, 2004).

Metode penarikan air menggunakan natrium sulfat anhidrat 
supaya menghasilkan minyak atsiri yang paling murni. Hasil pemurnian dilanjutkan identifikasi secara kualitatif dengan cara menganalisa sesuai parameter dan standar yang berlaku (Arswendiyumna, 2011). Jadi penelitian ini bertujuan menganalisa secara kuanitatif minyak atsiri dari tanaman serai (Cymbopogon sp.) sebagai aromaterapi.

\section{METODE PENELITIAN}

Pada penelitian ini menggunakan penelitian deskriptif kuantitatif dengan mejelaskan secara keselurahan tahapan ekstraksi minyak atsiri serai hingga identifikasi minyak atsiri sesuai dengan mutu standar yang berlaku. Identifikasi yang dilakukan meliputi perhitungan rendemen,organoleptik dan bobot jenis.

Bahan utama yang digunakan pada penelitian adalah serai, masingmasing perlakuan menggunakan serai sebanyak 300 gram. Tanaman serai yang digunakan merupakan hasil budidaya di Green House Prodi Farmasi Fakultas Ilmu Kesehatan Universitas Ibrahimy. Tempat pelaksanaan penelitian di Laboratorium Kimia Farmasi pada Bulan Maret-Agustus 2019.
Alat yang digunakan meliputi rotary evaporator, peralatan maserasi, gelas ukur, beaker gelas, neraca analitik, timbangan, pipet volume, labu ukur, blender, kertas saring, ayakan, nampan plastik, pisau, kaca arloji, batang pengaduk, pipet, handscoon, botol sampel, corong kaca, alat hidrodestilasi, vakum rotary evaporator, kamera, alat tulis,kertas label. Bahan yang digunakan terdiri dari tanaman serai dan akuades.

Tahapan penelitian ini meliputi:

\section{Persiapan Sampel Tanaman Serai}

Sampel serai yang digunakan masing-masing perlakuan sebanyak 300 gram dan dilakukan pemanenan pada pagi hari untuk menghindari penguapan minyak atsiri. Pemanenan dilakukan dengan cara dipangkas hingga bagian pangkal batang dan selanjutnya dilakukan sortasi dan dilanjutkan pencucian menggunakan air mengalir untuk menghilangkan kotoran yang masih menempel. Kemudian batang serai yang sudah bersih dirajang dengan tujuan mempercepat proses pengeringan dan dilanjutkan pengeringan pada nampan dengan cara dikering anginkan dan tidak terpapar sinar matahari secara langsung selama tiga hari. 


\section{Pengukuran Kadar Air Serai}

Pengukuran kadar air sampek dilakukan dengan cara mengeringkan serai dalam oven pada suhu $40^{\circ} \mathrm{C}$ selama 5 jam kemudian didinginkan dan ditimbang. Hasil yang diperoleh yaitu sebesar $6 \%$ hal ini menunjukkan bahwa kandungan air yang berasal dari Green house Program studi Farmasi Universitas Ibrahimy sudah memenuhi standar yaitu $<10$.

\section{Isolasi dan Pemeriksaan Minyak}

\section{Atsiri Serai}

Proses isolasi minyak atsiri sampel serai segar dan kering dilakukan dengan cara hidrodestilasi. Sampel serbuk serai (sampel seraikering) sebanyak 300 gram yang terendam akuades diperoleh minyak atsiri sebanyak $2.16 \mathrm{~mL}$. Pemeriksaan minyak atsiri yang dilakukan dengan cara meneteskan minyak sebanyak satu tetes diatas kertas saring dan ditunggu hingga tidak ada bekas atau kertas yang transparan. Tahapan selanjutnya dilakukan uji organoleptik meliputi rasa, warna dan bau.

Analisis data menggunakan analisis univariat yaitu mendeskripsikan karakteristik variabel penelitian dalam bentuk tabel distribusi frekuensi. Selanjutnya hasil pengukuran dibandingkan dengan standar SNI yang berlaku.

\section{HASIL DAN PEMBAHASAN}

Penetapan kandungan air dilakukan dengan cara mengeringkan batang serai 300 gram menggunakan oven pada suhu $40^{\circ} \mathrm{C}$ selama 5 jam. Selanjutnya didinginkan dan ditimbang bahan yang sudah di oven. Hasil perhitungan kandungan air serai yang berasal dari sebesar 6\% Green house Program studi Farmasi Universitas Ibrahimy dan memenuhi standar yaitu $<10$.

Tabel 1. Hasil Pengukuran Kadar Air Simplisia Serai

\begin{tabular}{|c|c|c|c|c|}
\hline \multicolumn{3}{|c|}{2} & \multicolumn{2}{|c|}{ Hasil } \\
\hline Sampel & Suhu & Waktu & $\begin{array}{c}\text { Kadar } \\
\text { Air }\end{array}$ & Standar \\
\hline $\begin{array}{c}\text { Simplisia } \\
\text { Serai } \\
\end{array}$ & $40{ }^{\circ} \mathrm{C}$ & $5 \mathrm{Jam}$ & $6 \%$ & $<10 \%$ \\
\hline
\end{tabular}

Berdasarkan hasil pemeriksaan minyak atsiri secara kualitatif dengan cara identifikasi minyak atsiri secara umum pada sampel serai kering di atas menunjukan bahwa serai yang diperoleh dari Green house Program studi Farmasi Universitas Ibrahimy terdapat kandungan minyak atsiri. 
Tabel 2. Hasil Rendemen Minyak Atsiri Serai

\begin{tabular}{lccc}
\hline Sampel & \multicolumn{3}{c}{ Pengukuran } \\
& $\begin{array}{c}\text { Berat } \\
\text { Sampel } \\
(\text { gram) }\end{array}$ & $\begin{array}{c}\text { Volume } \\
(\mathbf{m l})\end{array}$ & $\begin{array}{c}\text { Rendemen } \\
(\% \mathbf{v} / \mathbf{b})\end{array}$ \\
\hline Simplisia Serai & 300 & 2.16 & 0.72 \\
$\mathrm{X}$ & 300 & - & $0.97-1.2 \%$ \\
\hline
\end{tabular}

Hasil dari tabel 2, menunjukkan rata-rata rendemen yang diperoleh sebesar $0.72 \%$. Uji organoleptik diperoleh hasil minyak atsiri dari sampel serai kering menggunakan metode destilasi air sesuai dengan standar.

Tabel 3. Hasil Uji Organoleptik

\begin{tabular}{|c|c|c|c|c|}
\hline Sampel & Bentuk & $\begin{array}{l}\text { Ciri-ciri } \\
\text { Warna }\end{array}$ & Bau & Rasa \\
\hline $\begin{array}{c}\text { Simplisia } \\
\text { Serai }\end{array}$ & Cair & Kuning Muda & Khas & Getir \\
\hline $\mathrm{X}$ & Cair & $\begin{array}{l}\text { Kuning Muda } \\
\text { sampai } \\
\text { kecoklatan }\end{array}$ & Khas & Getir \\
\hline
\end{tabular}

Tabel 4. Hasil Bobot

\begin{tabular}{|c|c|c|}
\hline \multirow[b]{2}{*}{ Sampel } & \multicolumn{2}{|c|}{ Parameter } \\
\hline & $\begin{array}{c}\text { Bobot Jenis } \\
25^{0} \mathrm{C} \\
\end{array}$ & $\begin{array}{c}\text { SNI } \\
06-3953-1995 \\
\end{array}$ \\
\hline Simplisia Serai & $0,878 \mathrm{gr} / \mathrm{ml}$ & $0,876-0,919$ \\
\hline
\end{tabular}

Hasil bobot jenis dari sampel minyak atsiri serai kering diperoleh sebesar $0.878 \mathrm{gr} / \mathrm{ml}$ dan sesuai dengan standar SNI 06-3953-1995 yaitu bobot jenis minyak serai sekitar 0.876-0.919. Minyak atsiri pada tanaman biasanya memiliki bau khas atau aromatik (Muchtaridi, 2015). Kandungan minyak atsiri jika terhirup maka dapat berinteraksi dengan sistem saraf pusat dan langsung menuju sistem olfaktori hingga dapat menstimulasi kerja sistem saraf pada otak (Buckle, 1999).

Pada penelitian Muchtaridi (2015) menyatakan bahwa minyak atsiri dapat mempengaruhi aktivitas lokomotor pada mencit. Variasi minyak atsiri pada tanaman dipengaruhi oleh variasi genetik tanaman, letak geografis, waktu pemanenan, tahap pertumbuhan dan faktor lingkungan lainnya seperti suhu, kelembaban dan cahaya matahari (Naquvi et al, 2014). Penelitian yang oernah dialkuakan yaitu telah membuktikan bahwa minyak atsiri yang paling banyak bisanya berasal dari tanaman yang tumbuh di Negara tropis dan Mediterania (Bakkali et al, 2008).

Produk aromaterapi pada kesehatan memiliki manfaat untuk merelaksasikan tubuh, menyegarkan pikiran sehingga memperbaiki mood, dalam proses penyembuhan penyakit aromaterapi dapat meningkatkan efek fisiologi hingga mempercepat kesembuhan. Menurut beberapa penelitian yang telah dilakukan uji menyatakan bahwa minyak atsiri dalambentuk aromaterapi memiliki manfaat seperti anti oksidan, meredakan inflamasi, analgesic. Minyak atsiri pada 
sirih dan jeruk nipis dapat berfungsi sebagai immonomodulator (Ali, 2015).

$$
\text { Minyak atsiri sebagai }
$$

aromaterapi dapat digunakan sebagai teknik terapi beberapa penyakit sehingga dapat membantu menjaga kesehatan (Koensoemardiyah, 2009). Pada prosesnya aromaterapi yang berfungsi membantu meredakan gejala penyakit dan mampu mengontrol emosi dengan cara mempengaruhi sistem limik di otak (Astuti et al, 2015). Selain itu, aromaterapi mampu merangsang produksi neurohormon seperti endorphin dan enchepalin yang berfungsi untuk menghilangkan rasa sakit dan serotonin (Perez, 2003). Secara imunologi dapat meningkatkan jumlah limfosit dalam pembuluh darah perifer, CD8, CD16 yang berperan dalam sistem imunitas (Kuriyama et al., 2006). Cara penggunaan aromaterapi biasanya dengan cara dihirup sehingga kandungan minyak atsiri direspon oleh otak dan mempengaruhi fisik, emosional dan mental (Moelyono, 2015).

Minyak atsiri merupakan hasil dari metabolit sekunder melalui jalur asam mevalonat yang tergolong dalan senyawa terpen (Ganjewala, 2009). Penggunaan minyak atsiri saat ini sudah digunakan sebagai parfum, bahan campuran kosmetik, antibiotic, antioksidan, imunostimulan, mengurangi stress dan terapi untuk penyakit ringan lainnya (Buchbauer, 2010). Minyak atsiri telah dilakukan banyak kajian empiric terhadap tanaman penghasil senyawa aromatis di Indonesia yaitu terdapat 49 jenis tanaman aromatis, salah satu yang paling banyak diminati yaitu aromaterapi dai minyak serai dan dapat merelaksasikan tubuh (Sangat, 1996).

Secara organoleptik minyak atsiri biasanya memiliki rasa getir, berbau wangi khas dan berwarna bening atau jernih tergantung jenis tanamannnya, dapat larut dalam pelarut organik dan tidak mudah larut dalam pelarut air. Jika terpapar sinar matahari secara langsung dan udara maka kebanyakan minyak atsiri akan mudah teroksidasi dan menguap sehingga menurunkan kualitas dari minyak atsiri atau produknya (Pengelly, 2004). Saat ini minyak serai merupakan salah satu komoditas ekspor di Indonesianyang dapat meningkatkan pendapatan negara sehingga banyak dilakukan kajian dan pemanfaatan secara umum oleh beberapa industri (Deperindag, 2002). 


\section{SIMPULAN DAN SARAN}

Kesimpulan dari penelitian ini yaitu kandungan air simplisia serai sebesar $6 \%$ dan presentase rendemen minyak atsiri $0.72 \%$ v/b. Hasil uji organoleptik menunjukkan minyak atsiri simplisia serai berwarna kuning muda, berwujud cair, bau khas aromatik, rasa pahit/getir dengan bobot jenis sebesar $0.878 \mathrm{gr} / \mathrm{ml}$.

Saran dalam penelitian ini yaitu untuk penelitian selanjutnya dapat menggunakan serai dengan berbagai jenis dan metode ektraksi yang digunakan, sehingga mendapatkan perbandingan dan hasil yang paling optimal.

\section{DAFTAR PUSTAKA}

Arswendiyumna, R., et al. 2011. Minyak Atsiri dari Daun dan Batang Tanaman Dua Spesies Genus Cymbopogon, Famili Gramineae Sebagai Insektisida Alami dan Antibakteri. [Prosiding Skripsi Semester Genap]. Fakultas Matematika dan Ilmu Pengetahuan Alam Institut Teknologi Sepuluh Nopember Surabaya. Surabaya.

Ali B, et al.Essential Oils Used In Aromatherapy: A Systemic Review. Asian Pac J Trop Biomed.2015; 5(8):601-11.

Anonim. 2001. Inventaris Tanaman Obat Indonesia (1). Jilid 2.
Jakarta: Departemen Kesehatan RI.

Anonim. 2008. Modul Standarisasi Tanaman Obat. BBPPTOOT: Departemen Kesehatan RI.

Feriyanto, Y.E., et al. 2013. Pengembangan Minyak Atsiri dari Daun dan Batang Serai Wangi (Cymbopogon Winterianus) Menggunakan Metode Distilasi Uap dan Air dengan Pemanasan Microwave. Jurnal Teknik Pomits Vol.2, (1):93-97.

Ginting, S. 2004. Pengaruh Lama Penyulingan terhadap Rendemen dan Mutu Minyak Atsiri Daun Sereh Wangi. Fakultas Pertanian Universitas Sumatera Utara. Sumatera Utara.

Guenther, E. 1990. Minyak Atsiri. Jilid IV A. Jakarta: Universitas Indonesia Press.

Prayitno, S.A. 2006. Destilasi Minyak Atsiri Daun Sirih (Piper betle Linn.) yang Berasal dari Daerah Karanganyar dan Matesih. [Laporan Praktek Kerja Lapangan]. Fakultas Sains dan Matematika Salatiga: Universitas Kristen Satya Wacana Salatiga.

Sastrohamidjojo, H. 2004. Kimia Minyak Atsiri. Yogyakarta: Gadjah Mada University Press.

Satuhu, Y., dan Y. Sri. 2012. Panduan Lengkap Minyak Atsiri. Jakarta: Penebar Swadaya. 
